\title{
Set of STR-markers for 6 p21.31 chromosomal region linkage analysis and CNV study
}

\author{
N. V. Hryshchenko1, O. P. Kirichenkova ${ }^{2}$, V. V. Gordiyk ${ }^{1}$, S. A. Kravchenkoㄹ, \\ V. I. Kashuba ${ }^{1,3}$ \\ ${ }^{1}$ Institute of Molecular Biology and Genetics, NAS of Ukraine \\ 150, Akademika Zabolotnoho Str., Kyiv, Ukraine, 03143 \\ 2 EEducational and Scientific Center "Institute of Biology and Medicine", Taras Shevchenko National University of Kyiv \\ 64/13, Volodymyrska Str., Kyiv, Ukraine, 01601 \\ ${ }^{3}$ Karolinska Institutet \\ Stockholm SE-171 77, Sweden \\ n.v.hryshchenko@imbg.org.ua
}

The aim of the study is to create a panel of informative STR-markers in HLA locus for the analysis of genomic rearrangements in different types of malignant tumors as well as for the selection of the HLA matched sibling for allogeneic transplantation. Methods. The preliminary screening of six presumed STR-markers located in the proximal, central and distal parts of the HLA chromosome region (6p21.31) was performed by agarose gel electrophoresis of the PCR-fragments. The accurate genotyping of the most promising STR-markers was carried out by electrophoretic separation of the PCR-fragments in a polyacrylamide gel on an automatic laser analyzer. Results. Based on the obtained results we have selected three STRs with the highest heterozygosity indexes (HI): D6S2678 - HLA class I (HI=91.4 \%), DQIV - class II $(\mathrm{HI}=62.8 \%)$ and $\mathrm{D} 6 \mathrm{~S} 2925$ - class $\mathrm{III}(\mathrm{HI}=74.3 \%)$ as potential markers for linkage and $\mathrm{CNV}$ study. Conclusion. We have demonstrated that the selected panel of markers allows us to effectively solve both tasks: detection of somatic rearrangements in different parts of HLA locus in tumor samples and HLA-haplotype determination to select a suitable related donor for transplantation.

Ke y w or d s: STR-marker, HLA-haplotype, allogeneic transplantation, cancer, somatic rearrangement.

\section{Introduction}

HLA (Human Leukocyte Antigens) on the lion base pairs) encode cell surface glycoproshort arm of chromosome 6 (6p21.31, 4 mil- teins of human Major Histocompatibility

(C) 2019 N. V. Hryshchenko et al.; Published by the Institute of Molecular Biology and Genetics, NAS of Ukraine on behalf of Biopolymers and Cell. This is an Open Access article distributed under the terms of the Creative Commons Attribution License (http://creativecommons.org/licenses/by/4.0/), which permits unrestricted reuse, distribution, and reproduction in any medium, provided the original work is properly cited 
Complex (MHC). More than 200 HLA-genes are organized into 3 chromosome loci according to the functions of expressed antigens (class I-III). MHC proteins are involved in inducing and regulation of human immune response. The class I proteins form the complex with an antigen for recognition by cytotoxic CD8+ $\mathrm{T}$ cells and are also involved in the initiation of transplant immunity. The class II molecules represent an antigen to CD4+ T-helpers and CD4+ T-inflammation cells and initiate the transplant immunity. The class III genes encode SS and SLP complement proteins and TNF- $\alpha$ and TNF- $\beta$ cytokines.

It is known that an increased rate of somatic rearrangements such as $\mathrm{CNV}$ (Copy Number Variations) leading to deletion and duplications in the HLA genes is one of the possible mechanisms of immune evasion in the development and progression of some types of cancers [1-3]. On the other hand, HLA haplotypes allow the selection of siblings that are HLA matched with a patient who is in need of an allogeneic transplantation [4]. Because of the $25 \%$ probability of a sibling to inherit the same alleles of HLA locus as the patient, the favorable outcome of such transplantation is much higher than the selection by HLA phenotypes of a partially HLA-mismatched donor.

The short tandem repeat (STR) polymorphisms are the DNA-regions consisting of a polymorphic number of 2-6 nucleotides' units, which occur frequently in the human genome and are widely used in different molecular diagnostic applications (parentage identification, linkage studies, germline and somatic deletion/duplication identification and others) [5]. The main diagnostic characteristics of
STRs are their heterozygosity indexes and the number of different alleles in the studied population. Therefore, to choose the panel of the most informative diagnostic STRs, the genetic characterization of the chosen DNAmarkers is needed.

The aim of the study is to create a panel of informative STR-markers from three regions of the HLA locus for the analysis of genomic rearrangements in different types of malignant tumors as well as for selection of the HLA matched sibling for allogeneic transplantation.

\section{Patients and Methods}

The objects of our study are the DNA samples from blood leucocytes of 35 healthy volunteers, the members of 10 core families (both parents and children with confirmed biological paternity status) and from the surgical material of 15 patients with ovarian tumors. The DNA samples used in the current study were taken from the previously collected DNA biobank [6-7]. All participants involved in the DNA biobanking gave the informed consent to participate in the research studies.

For STR genotyping of the samples, PCR followed by fragment analysis was used. The preliminary analysis of six previously published STR-markers from HLA locus [8-9] was performed using $2 \%$ agarose gel for the separation of STR-alleles. The most polymorphic markers were selected for further analysis. One of the PCR-primers for each selected STRmarker amplification was labeled by $\mathrm{Cy} 5 \mathrm{flu}-$ orescent dye fabricated by Methabion, Germany. PCR mixture $(15 \mu \mathrm{l})$ contained $1 \mathrm{x}$ FIREPol ${ }^{\circledR}$ Master Mix Ready to Load with $7.5 \mathrm{mM} \mathrm{MgCl}_{2}$ (Solis BioDyne), $60 \mu \mathrm{mol}$ primers and 300 ng of gDNA. PCR was carried 
out on 9200 Thermal Cycler (Applied Biosystems), 30 cycles, $60^{\circ} \mathrm{C}$ - annealing temperature. The fragment analysis of the STRmarkers was carried out by electrophoretic separation of the PCR products in a $7 \%$ denaturated polyacrylamide gel on the automatic laser analyzer ALF-express II (Pharmacia Biotech). The allele discrimination and allelic imbalance were analyzed using ALF-express Fragment Manager Software.

The study of genomic rearrangements in the $H L A$ region was performed using $\mathrm{LOH}$ analysis of the STR-markers. The marker was informative for the LOH-study if the patient's normal sample was heterozygous of this marker. The limits of $\mathrm{LOH}$ value according to international recommendations were $0.67>\mathrm{AI}$ $>1.35$ (AI - allelic imbalance). HLA haplotype linkage analysis of families was performed for all family members (mother, father, and two or more siblings), in order to identify the informative STR markers to detect the
HLA haplotypes of each family member. The STR marker was considered to be informative when both parents were heterozygous for this marker, and the STR-alleles differed in size in mother and father. In the case where parents were heterozygous for the same alleles, the marker was considered informative if the recipient child was a homozygote for either of the two parental alleles.

\section{Results and Discussion}

We tested 6 STR-markers (2 each in proximal, central and distal areas of HLA-locus) on the DNA samples of conventionally normal individuals from Ukraine. According to the results of fragment analysis in agarose gel, 3 potential markers for the study of their informativeness were selected: D6S2678 (class I), DQIV (class II) and D6S2925 (class III), which according to preliminary data had the highest heterozygosity indexes. To determine the exact size of PCR-products of the STR-markers se-

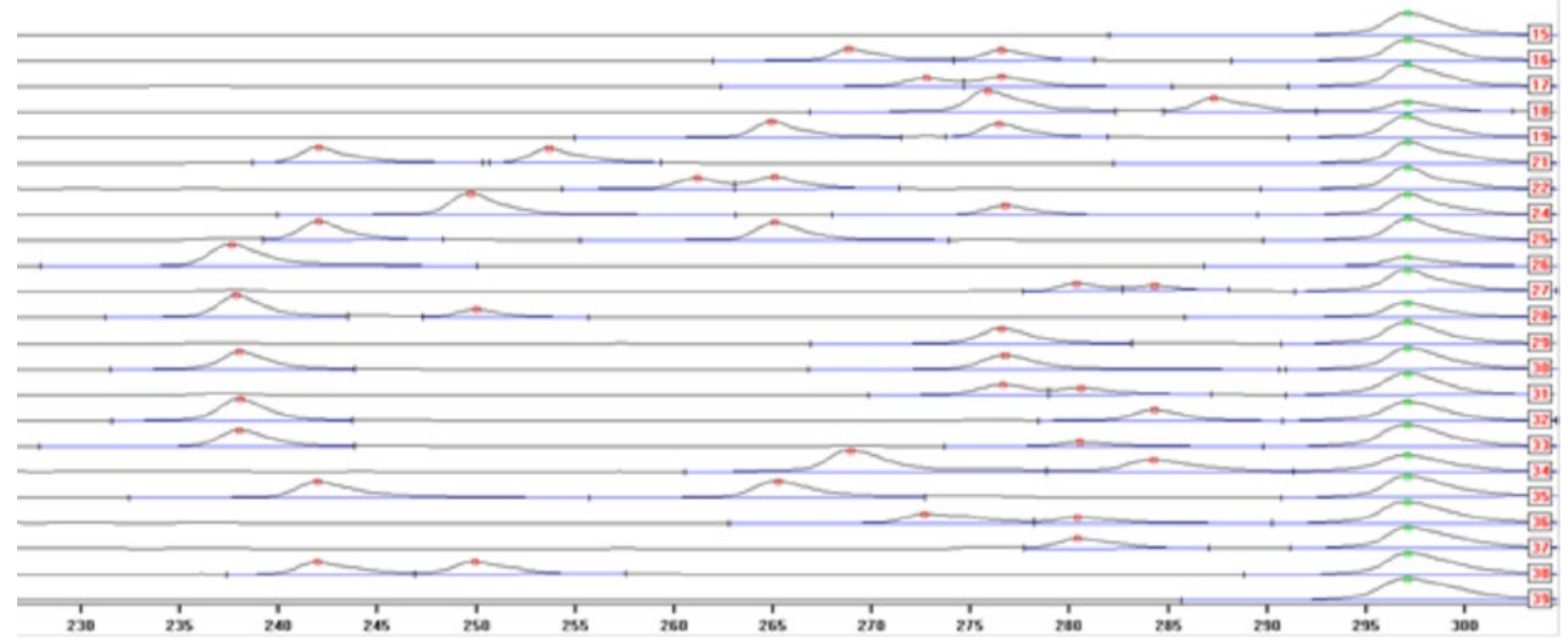

Fig.1. An example of allelic distribution of the marker D6S2678, ALF-fluorogram of the PCR products 
N. V. Hryshchenko, O. P. Kirichenkova, V. V. Gordiyk et al.

Table 1. Diagnostic characteristics of the STR-markers of HLA-region

\begin{tabular}{l|l|c|c}
\hline \multicolumn{1}{c|}{ Marker } & \multicolumn{1}{c|}{ HLA locus and genes } & N of alleles & HI \\
\hline D6S2678 & Class I: HLA-E - HLA-C & 12 & $91.4 \%$ \\
\hline DQIV & Class II: DQB1-DOB & 9 & $62.8 \%$ \\
\hline D6S2925 & Class III:HLA-B-MICB & 11 & $74.3 \%$ \\
\hline
\end{tabular}

HI - Heterozygosity Index

lected in the previous step, the analysis was performed using ALF express II (fig. 1).

Based on the results of the analysis of 35 unrelated DNA samples, the heterozygosity index of each STR-marker was determined (Table 1). The selected STRs have been characterized by the allele variety and the level of heterozygosity in the studied group.
A large number of alleles and high heterozygosity indexes indicate that the selected STR-markers are highly informative for both LOH HLA-analysis and linkage HLAhaplotype analysis.

Using the selected panel of markers, the preliminary HLA-haplotype analysis in several core families (parents and children) and LOH analy-

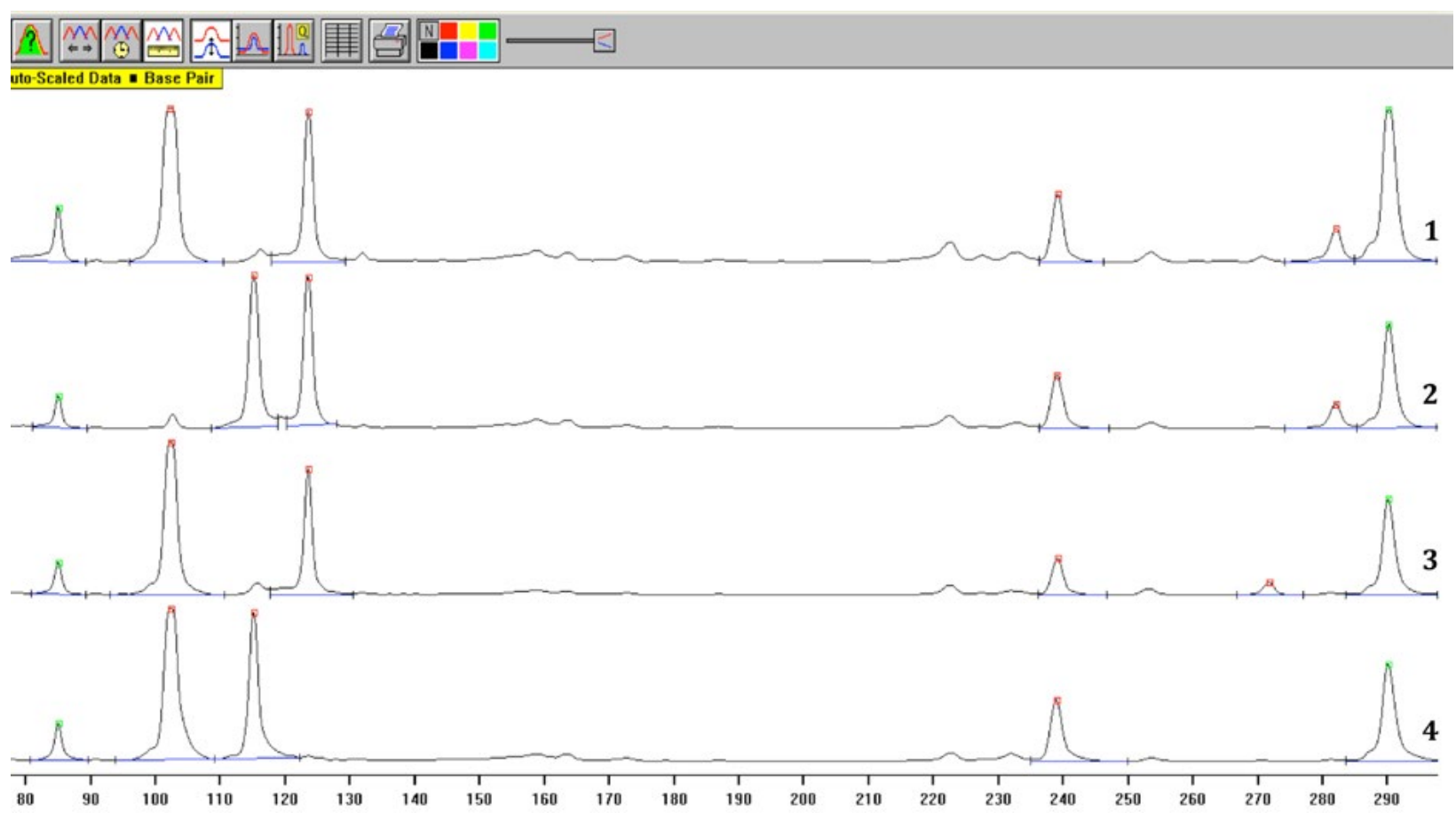

Fig. 2. Linkage analysis of HLA-haplotypes of D6S2925 and D6S2678 STR-markers: 1 - proband, 2 - mother, 3 father, 4 -sibs. The proband and his sibling inherited the same HLA-haplotype from their father and different HLAhaplotypes from their mother. 


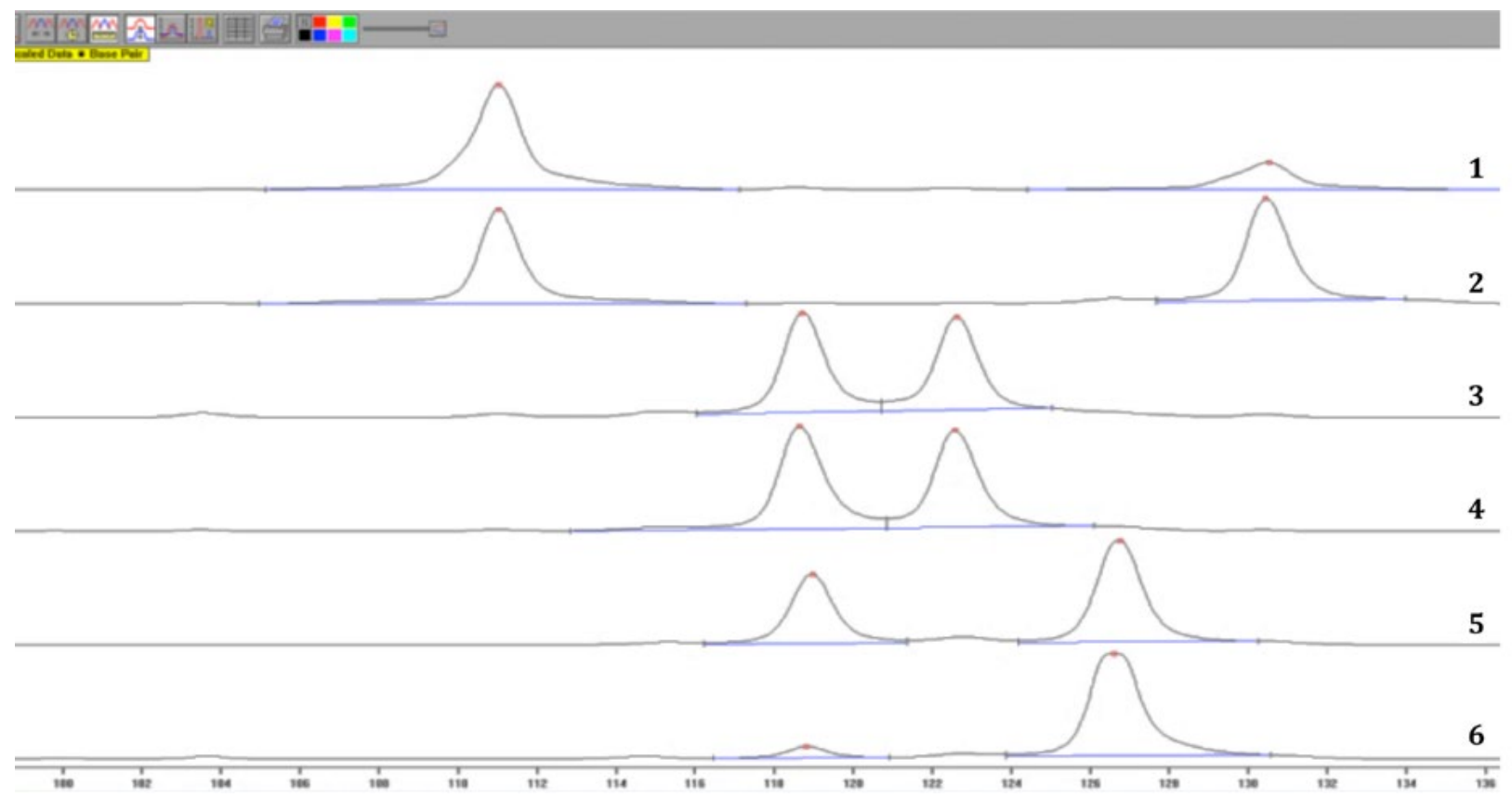

Fig. 3. ALF-fluorogram of PCR-fragments of D6S2925 in patients with ovarian cancer: 1, 3, 5 - tumor samples of the patients ov15, ov22 and ov23; 2, 4, 6 - the corresponding samples of normal tissues. $\mathrm{AI}($ ov 15) $=3.7 ; \mathrm{AI}(\mathrm{ov} 22)=0.9$; $\mathrm{AI}(\mathrm{ov} 23)=9.2$.

sis in paired samples of ovarian tumor tissue (tumor-normal) were carried out. The examples of both types of analyzes are shown in figures 2 and 3. The shown cases were fully informative.

\section{LOH-analysis:}

AR (allele ratio) - ratio of the intensity of the alleles in 1 sample:

$\mathrm{S}-$ peak area of the allele

$$
\mathbf{A R}=\mathbf{S}_{\text {alele1 }} / \mathbf{S}_{\text {alele2 }}
$$

AI (allelic imbalance) - ratio of AR values of normal and tumor sample of the patient:

$$
\mathbf{A I}=\mathbf{A} \mathbf{R}_{\text {normal }} / \mathbf{A} \mathbf{R}_{\text {tumor }}
$$

The HLA-haplotype analysis revealed that the sibling could not be the fully matched donor to the patient as far as he inherited different HLA-alleles from mother by both STRmarkers. So, the offsprings in the current family are partial HLA-matched relatives. Noteworthy, the HLA region is a hot spot of genomic rearrangements. Thus, to predict the crossing-over events and avoid misdiagnosis in a linkage analysis, we used 3 markers from different parts of the HLA-region. This allows us to determine the HLA haplotype that is inherited from mother and father by each child even in the case of crossing-over.

$\mathrm{LOH}$-analysis detects partial deletion in HLA class III region in 2 out of 3 shown ovarian tumors (ov15 and ov23). In the studied group of 15 patients with ovarian cancer, 8 partial deletions of at least one of the studied HLA-loci were identified. Thus, we may pre- 
dict that these patients would have an incorrect response to immunotherapy due to impaired inflammatory processes [10]. However, to confirm this hypothesis, further research is needed in an enlarged group of patients as well as an analysis of expression of HLA-genes located in the somatic deletions' region.

\section{Conclusions}

The analysis using the D6S2678 (class I), DQIV (class II) and D6S2925 (class III) STR markers allows us to determine the somatic rearrangements of the HLA region in malignant tumors, which could be used to predict the immunotherapy effectiveness and treatment outcome in cancer patients. The current panel of markers could also be used to detect HLA matched sibling for allogeneic transplantation. This method is highly informative, inexpensive, and low labor-intensive; therefore, it could be recommended for a routine diagnostics.

\section{REFERENCES}

1. Chowell D, Morris LGT, Grigg CM, Weber JK, Samstein RM, Makarov V, Kuo F, Kendall SM, Requena D, Riaz N, Greenbaum B, Carroll J, Garon E, Hyman DM, Zehir A, Solit D, Berger M, Zhou R, Rizvi NA, Chan TA. Patient HLA class I genotype influences cancer response to checkpoint blockade immunotherapy. Science. 2018;359(6375):582-587.

2. Doonan BP, Haque A. Prostate Cancer Immunotherapy: Exploiting the HLA Class II Pathway in Vaccine Design. J Clin Cell Immunol. 2015;6(4). pii: 351.

3. Scepanovic P, Alanio C, Hammer C, Hodel F, Bergstedt J, Patin E, Thorball CW, Chaturvedi N, Charbit B, Abel L, Quintana-Murci L, Duffy D, Albert ML, Fellay J; Milieu Intérieur Consortium. Human genetic variants and age are the strongest predictors of humoral immune responses to common pathogens and vaccines. Genome Med. 2018;10(1):59.
4. Howard CA, Fernandez-Vina MA, Appelbaum FR, Confer DL, Devine SM, Horowitz MM, Mendizabal A, Laport GG, Pasquini MC, Spellman SR. Recommendations for donor human leukocyte antigen assessment and matching for allogeneic stem cell transplantation: consensus opinion of the Blood and Marrow Transplant Clinical Trials Network (BMT CTN). Biol Blood Marrow Transplant. 2015;21(1):4-7.

5. Willems T, Gymrek M, Highnam G; 1000 Genomes Project Consortium, Mittelman D, Erlich Y. The landscape of human STR variation. Genome Res. 2014;24(11):1894-904.

6. Kashuba V, Dmitriev AA, Krasnov GS, Pavlova T, Ignatjev I, Gordiyuk VV, Gerashchenko AV, Braga EA, Yenamandra SP, Lerman M, Senchenko VN, Zabarovsky E. NotI microarrays: novel epigenetic markers for early detection and prognosis of high grade serous ovarian cancer. Int $J$ Mol Sci. 2012;13(10):13352-77.

7. Fesai OA, Kravchenko SA, Tyrkus MY, Makukh GV, Zinchenko VM, Strelko GV, Livshits LA. CAG polymorphism of the androgen receptor gene in azoospermic and oligozoospermic men from Ukraine. Cytol Genet. 2009; 43:401-5.

8. Bick SL, Bick DP, Wells BE, Roesler MR, Strawn EY, Lau EC. Preimplantation HLA haplotyping using tri-, tetra-, and pentanucleotide short tandem repeats for HLA matching. J Assist Reprod Genet. 2008;25(7):323-31.

9. Cullen M, Malasky M, Harding A, Carrington M. High-density map of short tandem repeats across the human major histocompatibility complex. Immunogenetics. 2003;54(12):900-10.

10. Deakin JE, Papenfuss AT, Belov K, Cross JG, Coggill P, Palmer S, Sims S, Speed TP, Beck S, Graves JA. Evolution and comparative analysis of the MHC Class III inflammatory region. BMC Genomics. 2006;7:281.

\section{Панель STR-маркерів для аналізу зчеплення та CNV хромосомної ділянки 6р21.31}

Н. В. Грищенко, О. П. Кіріченкова, В. В. Гордіюк, С. А. Кравченко, В. І. Кашуба

Метою дослідження є створення панелі інформативних STR-маркерів локусу HLA для аналізу геномних пере- 
будов при різних типах злоякісних пухлин, а також для вибору HLA-сумісного спорідненого донора для алогенних трансплантацій. Методи. Попередній скринінг шести передбачуваних STR-маркерів, розташованих в проксимальному, центральному та дистальному відділах хромосомної області HLA (6p21.31), проводили за допомогою електрофорезу ПЛР-фрагментів в агарозному гелі. Точне генотипування найбільш перспективних STR-маркерів проводилося шляхом електрофоретичного фракціонування ПЛР-фрагментів в поліакриламідному гелі на автоматичному лазерному аналізаторі. Результати. На підставі отриманих результатів відібрано три STR-локуса 3 найвищими індексами гетерозиготности (IГ): D6S2678 - HLA класу I (IГ = 91,4 \%), DQIV - класу II (IГ = 62,8 \%) і D6S2925 класуIII ( IГ =74,3 \%) в якості потенційних маркерів для дослідження внутрісімейного зчеплення і аналізу CNV. Висновки. Продемонстровано, що обрана панель маркерів дозволяє ефективно вирішувати обидва завдання: виявлення соматичних реорганізацій в різних ділянках локусу HLA в зразках пухлин і визначення HLA-гаплотипу для вибору підходящого родинного донора для трансплантації.

Кл юч о в і с с о в а: STR-маркер, HLA-гаплотип, алогенна трансплантація, рак, соматична реорганізація.

\section{Панель STR-маркеров для анализа сцепления и CNV хромосомной области 6р21.31}

Н. В. Грищенко, А. П. Кириченкова, В. В. Гордиюк, С. А. Кравченко, В. И. Кашуба

Целью исследования является создание панели информативных STR-маркеров локуса HLA для анали- за геномных перестроек при различных типах злокачественных опухолей, а также для выбора HLAсовместимого родственного донора для аллогенной трансплантации. Методы. Предварительный скрининг шести предполагаемых STR-маркеров, расположенных в проксимальном, центральном и дистальном отделах хромосомной области HLA $(6 \mathrm{p} 21,31)$, проводили с помощью электрофореза ПЦРфрагментов в агарозном геле. Точное генотипирование наиболее перспективных STR-маркеров проводилось электрофоретическим разделением ПЦРфрагментов в полиакриламидном геле на автоматическом лазерном анализаторе. Результаты. На основании полученных результатов мы отобрали три STR-локуса с наивысшими индексами гетерозиготности (ИГ): D6S2678 - HLA класса I (ИГ = 91,4 \%), DQIV - класса II (ИГ $=62,8 \%$ ) и D6S2925 - класс III (ИГ $=74,3 \%)$ в качестве потенциальных маркеров для исследования внутрисемейного сцепления и анализа CNV. Выводы. Продемонстрировано, что выбранная панель маркеров позволяет эффективно решать обе задачи: обнаружение соматических реорганизаций в различных участках локуса HLA в образцах опухолей и определение HLA-гаплотипа для выбора подходящего родственного донора для трансплантации.

Кл юч е в ы е сл о в a: STR-маркер, HLA-гаплотип, аллогенная трансплантация, рак, соматическая реорганизация.

Received 15.03.2019 